\title{
A case study on the occurrence of regional debris flow hazard in central Taiwan
}

\author{
C.-C. Lee ${ }^{1}$, C.-Y. Ku ${ }^{2,3}$, S.-M. Hsu ${ }^{2}$, Y.-L. Chang ${ }^{2}$ \& S.-Y. Chi ${ }^{2}$ \\ ${ }^{1}$ National Chung Hsing University, Taiwan, R.O.C. \\ ${ }^{2}$ Sinotech Engineering Consultants, Inc., Taiwan, R.O.C. \\ ${ }^{3}$ National Taiwan Ocean University, Taiwan, R.O.C.
}

\begin{abstract}
Large-scale debris flow hazards occurred in Ta-Chia River watershed during typhoons that passed through Taiwan from 2001 to 2005 without forewarning. Especially, the Minduli typhoon event in 2004 hit Taiwan which caused severe property damage and inflicted heavy casualties. Though landslide-induced debris flows present a hazard that is being increasingly recognized, such a large-scale debris flow hazard in Ta-Chia River watershed still appears to be particular. Until now, few detailed case studies of regional debris flow hazards in Ta-Chia River watershed have been presented in the literature. In this paper, we present a detailed study on the occurrence of regional debris flow hazard in Ta-Chia River watershed and reveal the trigger mechanism of the landslide and debris flow. To explore the coupling between the Chi-Chi earthquake and sequential regional debris flow hazards in Ta-Chia River watershed, the remote sensing data, Digital Elevation Model (DEM), historical landslides, and rainfall data were adopted in this study. For characterizing temporal aspects of the hazard, aerial photographs and satellite images of multi-temporal stages were used. Spatial distribution of landslides and rainfall characteristics were also discussed. Our findings indicate that the regional debris flow hazards were mainly caused by the huge amount of sparsely deposited materials from landslides triggered by Chi-Chi earthquake. Rapidly increasing water pressure caused by typhoon events provided a powerful force that moved the sparsely deposited materials into gullies and then triggered the debris flow movement. A strong coupling between the spatial distribution of rainfalls and the occurrence of regional debris flows is also addressed.
\end{abstract}

Keywords: debris flow, landslide, rainfall intensity, Chi-Chi earthquake, Taiwan. 


\section{Introduction}

Observations of landslides and debris flows have been reported for many decades. Historically typhoon events with high-intensity, long-duration rainfall often triggered shallow, rapidly moving landslides, i.e. debris flows, resulting in casualties and property damage in Taiwan along the past decades. It is widely recognized that slope instability can be caused by increased subsurface pore pressures during periods of intense rainfall. A number of studies have demonstrated that rainfall-induced landslides can be transformed into debris flows as they move downslope.

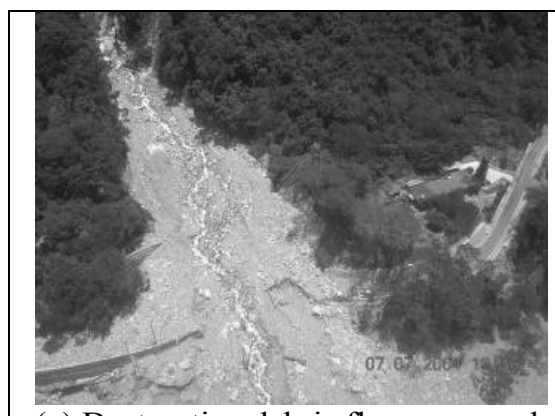

(a) Destructive debris flow occurred.

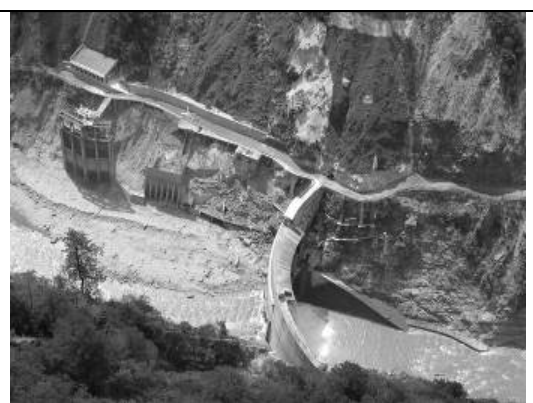

(b) Hydropower facilities damaged.

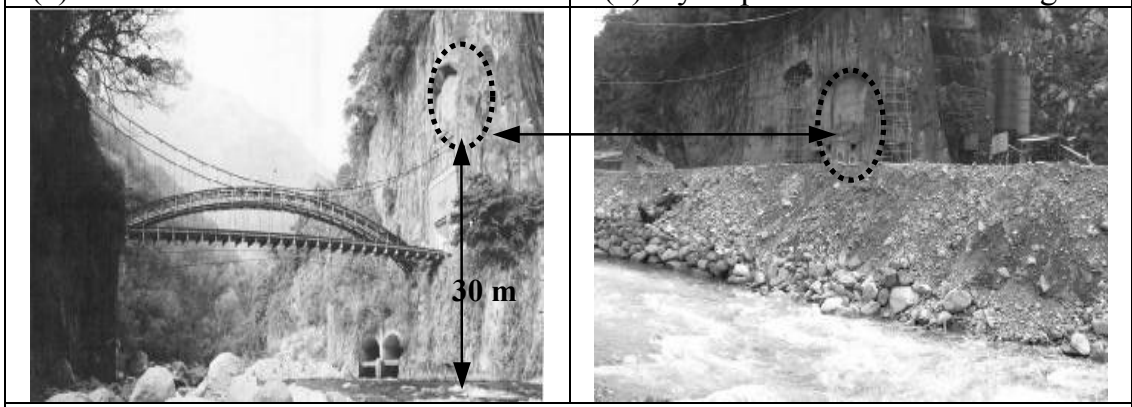

(c) Dramatic alteration of Ta-Chia riverbed before the Chi-Chi earthquake (left) after the Mindulle typhoon. (right)

Figure 1: $\quad$ Debris flow hazards in the study area.

Large-scale debris flow hazards occurred in Ta-Chia River watershed during typhoons that passed through Taiwan from 2001 to 2005 without forewarning. Especially, the Minduli typhoon event in 2004 hit Taiwan which caused severe property damage and inflicted heavy casualties as shown in Figure 1. Though landslide-induced debris flows present a hazard that is being increasingly recognized, such a large-scale debris flow hazard in Ta-Chia River watershed still appears to be particular. On September 21, 1999, the Chi-Chi earthquake was triggered by the reactivation of the Chelungpu fault near Chi-Chi in central Taiwan. This earthquake triggered numerous landslides and severely disturbed 
montane slopes. However, the debris flow hazard did not appear in the first two years after this earthquake. Post-earthquake watershed restoration works progressed without disruptions until several typhoon events with intense rainfall, such as (1) Toraji in 2001, (2) Minduli in 2004, (3) Airi in 2004, and (4) Hytarng in 2005, hit Taiwan and triggered numerous debris flows in central Taiwan and caused significant property damage and inflicted heavy casualties in regional scale.

Until now, few detailed case studies of regional debris flow hazards in TaChia River watershed have been presented in the literature. In this paper, we present a detailed study on the occurrence of regional debris flow hazard in TaChia River watershed and reveal the trigger mechanism of the landslide and debris flow. To explore the coupling between the Chi-Chi earthquake and sequential regional debris flow hazards in Ta-Chia River watershed, the remote sensing data, Digital Elevation Model (DEM), historical landslides, and rainfall data were adopted in this study. For characterizing temporal aspects of the hazard, aerial photographs and satellite images of multi-temporal stages were adopted. Spatial distribution of landslides and rainfall characteristics were also discussed.

\section{Study region}

The study region includes a major river, named Ta-Chia river, one of the abundant water resources in central Taiwan as shown in Figure 2. The Ta-Chia river watershed area is about $1,236 \mathrm{~km}^{2}$. The elevation of the highest mountain in the watershed is around $3,875 \mathrm{~m}$. The river stretch extends $124 \mathrm{~km}$ from upstream to the sea. This river valley is notable because it incorporates the Central Cross Island road that links the east and west coasts of Taiwan across the Central Mountains. A series of significant hydroelectric schemes that extend along the length of the river, consisting of one high, concrete arch dam at TeChi, and a series of dams and hydropower stations were built in 1960s. There are

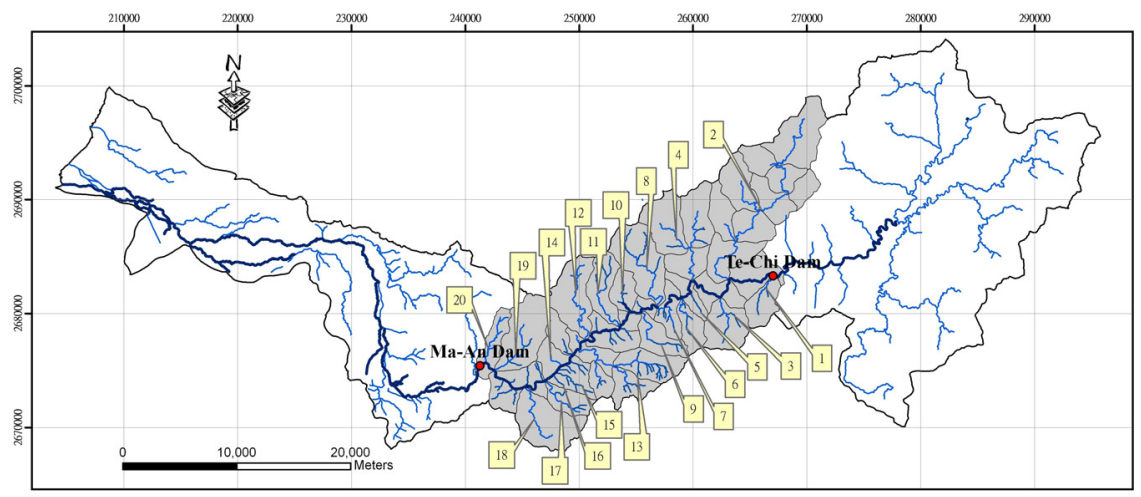

Figure 2: $\quad$ Study region and tributaries. 
also many tributaries along the Ta-Chia river. In our study region, about 20 tributaries were found between Te-Chi dam and Ma-An dam. The area of our study region is $396.5 \mathrm{~km}^{2}$. Since severe debris flow hazards were occurred in this region, the following discussion focused on it.

\subsection{Geological setting}

The study area consists of a steeply incised valley orientated approximately eastwest in the eastern part of the Central Range. The geology consists of a series of interbedded Tertiary sandstones and slates, with occasional limestone bands. The geologic strata of Ta-Chia river are argillite, slate, quartzite, sandstone, siltstone and shale including Lushan Formation, Tatungshan Formation, Kankou Formation, Chiayang Formation, Szeleng Sandstone, Tachien Sandstone, Kuohsing Formation, Guandaoshan Formation, Jinshuei Formation and Jhuolan Formation as shown in Figure 3. The rock mass is extensively tectonically disrupted, with a high density of fractures and joints. The slope inclination in the watershed is ranging from 40 to 80 degrees.

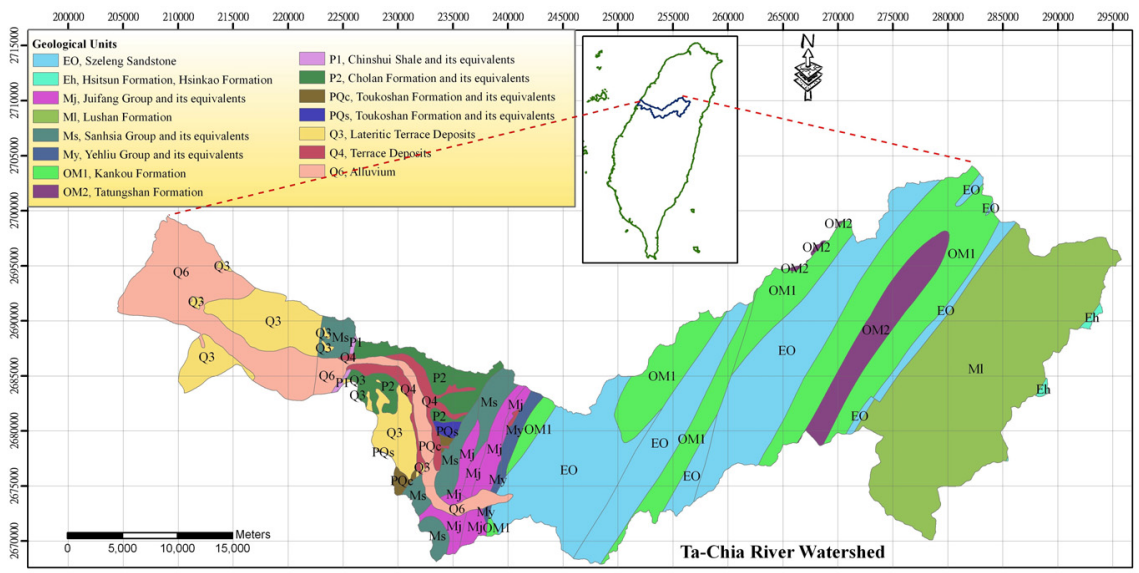

Figure 3: Location of Ta-Chia river watershed in Taiwan and its geological map.

\subsection{Major debris flow storm events in the study area}

During 1996 to 2005, according to the Central Weather Bureau of Taiwan, the following storm events including typhoon Herb in 1996, typhoon Toraji in 2001, typhoon Minduli in 2004, typhoon Airi in 2004, and Hytarng in 2005 have hit the study area. Within this period, the Chi-Chi earthquake on 21 September 1999 which is the largest in Taiwan for 50 years, was also occurred. This typhoonearthquake-typhoon sequence represents a natural experiment that provides quantitative information about the impact of a large earthquake on landslides and transfer of sediment to debris flows. 


\section{Occurrence of regional debris flow hazards}

\subsection{Landslide mapping}

Shallow landsliding is the most common landslide type on steep natural hillslopes in the Ta-Chia river watershed. Multi-temporal remote sensing data including aerial-photograph and SPOT satellite imaginary were used for landslide mapping. For characterizing temporal aspects of the debris flows, remote sensing data include aerial photographs and satellite images of five temporal stages which are the stage before and after Chi-Chi earthquake, the stage after typhoon Toraji, the stage after typhoon Minduli, the stage after typhoon Airi and Hytarng. Table 1 shows before and after the Chi-Chi earthquake (1989) the landslide rates are $0.68 \%$ and $7.54 \%$ respectively. After typhoon Toraji in 2001, typhoon Minduli in 2004, and typhoon Airi in 2004, the landslide rates are $6.05 \%, 7.80 \%$, and, $6.92 \%$ respectively. Comparing the landslide rate from these events, it is found that the Chi-Chi earthquake has caused significant landslides in the study region.

Table 1: Landslide area mapping from multi-temporal remote sensing data.

\begin{tabular}{|c|c|c|c|c|}
\hline & $\begin{array}{c}\text { Landslide } \\
\text { area }\left(\mathrm{km}^{2}\right)\end{array}$ & Landslide rate & $\begin{array}{c}\text { Increase } \\
\text { area }\left(\mathrm{km}^{2}\right)\end{array}$ & Increase rate \\
\hline Before Chi-Chi earthquake & 2.69 & $0.68 \%$ & $\sim$ & $\sim$ \\
\hline After Chi-Chi earthquake & 29.91 & $7.54 \%$ & 28.34 & $7.15 \%$ \\
\hline After typhoon Toraji & 23.99 & $6.05 \%$ & 6.68 & $1.68 \%$ \\
\hline After typhoon Minduli & 30.94 & $7.80 \%$ & 14.04 & $3.54 \%$ \\
\hline After typhoon Airi & 27.43 & $6.92 \%$ & 6.68 & $1.69 \%$ \\
\hline
\end{tabular}

Note: The landslide rate is the landslide area divided by watershed area $(396.5 \mathrm{~km} 2)$.

Furthermore, we computed the new landslides triggered by each event and found that the increase rates of slope failures occurred by these events are $7.15 \%$, $1.68 \%, 3.54 \%$, and $1.69 \%$ for four events including the Chi-Chi earthquake,

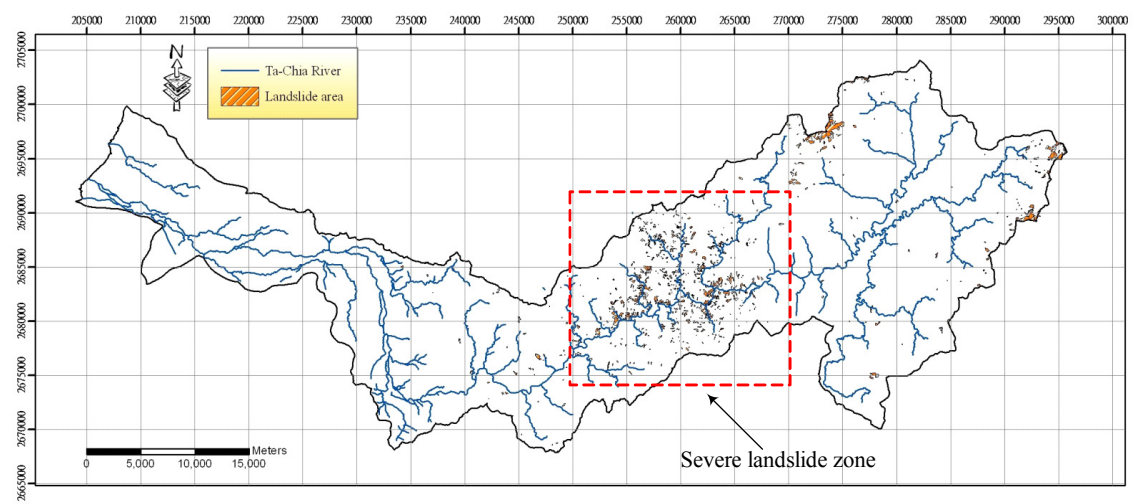

Figure 4: Spatial distribution of landslide areas. 
typhoon Toraji, typhoon Minduli, and typhoon Airi, respectively. Accordingly, we have revealed that the Chi-Chi earthquake with the landslide increase rate of $7.15 \%$ is the major event for inducing the landslides and typhoon Minduli with the landslide increase rate of $3.54 \%$ is the second. From the results of landslide mapping as shown in Figure 4, we found that the landslides were most located in the areas between Te-Chi dam and Ma-An dam.

\subsection{Characteristics of major debris flows}

Table 2 shows the occurrence record of the debris flows in the study region. Before the Chi-Chi earthquake, no observations of debris flows have been reported for decades. After the Chi-Chi earthquake and the first typhoon Toraji hit the region in 2001, three branch rivers (\# 13, \#14, and \#17) with the occurrence of debris flow have been reported. Severe debris flow hazards have been reported during the typhoon Minduli in 2004. The occurrence of debris flow was found in almost all of the branches, except one in the downstream. The following two typhoon events such as Airi in 2004 and Hytarng in 2005 also moved huge amount of debris sediment from these branch rivers into the main Ta-Chia river.

Table 2: $\quad$ Occurrence record of the debris flows.

\begin{tabular}{|c|c|c|c|c|c|c|c|c|}
\hline $\begin{array}{c}\text { Branch } \\
\text { river } \#^{1}\end{array}$ & $\begin{array}{c}\text { Watershed } \\
\text { area }\end{array}$ & $\begin{array}{c}\text { Watershed } \\
\text { slope }\end{array}$ & $\begin{array}{c}\text { Branch } \\
\text { river } \\
\text { slope }\end{array}$ & $\begin{array}{c}\text { Landslide } \\
\text { rate }(\%)\end{array}$ & $\begin{array}{c}\text { Occurrence } \\
\text { of debris } \\
\text { flow }\end{array}$ & $\begin{array}{c}\text { Occurrence } \\
\text { of debris } \\
\text { flow }^{3}\end{array}$ & $\begin{array}{c}\text { Occurrence } \\
\text { of debris } \\
\text { flow }\end{array}$ & $\begin{array}{c}\text { Occurrence } \\
\text { of debris } \\
\text { flow }\end{array}$ \\
\hline 1 & 8.86 & 33.8 & 11.5 & 10.26 & No & Yes & Yes & Yes \\
\hline 2 & 88.24 & 33.5 & 3.2 & 4.87 & No & Yes & Yes & Yes \\
\hline 3 & 13.74 & 37.0 & 20.2 & 17.83 & No & Yes & Yes & Yes \\
\hline 4 & 36.30 & 35.5 & 6.6 & 16.82 & No & Yes & Yes & Yes \\
\hline 5 & 1.98 & 40.0 & 24.6 & 40.73 & No & Yes & Yes & Yes \\
\hline 6 & 7.35 & 36.1 & 13.9 & 17.57 & No & Yes & Yes & Yes \\
\hline 7 & 3.49 & 40.4 & 21.0 & 32.50 & No & Yes & Yes & Yes \\
\hline 8 & 22.12 & 33.2 & 7.1 & 18.68 & No & Yes & Yes & Yes \\
\hline 9 & 9.70 & 35.9 & 13.1 & 24.21 & No & Yes & Yes & Yes \\
\hline 10 & 6.76 & 37.2 & 15.2 & 29.73 & No & Yes & Yes & Yes \\
\hline 11 & 12.12 & 32.7 & 6.8 & 9.56 & No & Yes & Yes & Yes \\
\hline 12 & 18.57 & 31.1 & 5.6 & 10.65 & No & Yes & Yes & Yes \\
\hline 13 & 31.09 & 34.4 & 7.6 & 12.34 & Yes & Yes & Yes & Yes \\
\hline 14 & 3.66 & 32.1 & 9.2 & 21.27 & Yes & Yes & Yes & Yes \\
\hline 15 & 3.75 & 32.5 & 14.3 & 15.44 & No & Yes & Yes & Yes \\
\hline 16 & 0.57 & 32.6 & 21.7 & 11.10 & No & Yes & Yes & Yes \\
\hline 17 & 7.76 & 30.8 & 10.0 & 7.88 & Yes & Yes & Yes & Yes \\
\hline 18 & 20.50 & 28.9 & 4.4 & 11.64 & No & Yes & Yes & Yes \\
\hline 19 & 20.89 & 30.4 & 6.2 & 11.34 & No & Yes & Yes & Yes \\
\hline 20 & 5.98 & 28.2 & 9.5 & 4.23 & No & No & No & No \\
\hline
\end{tabular}

${ }^{1}$ The branch river \# is shown in Figure $2 .{ }^{2}$ After typhoon Toraji in $2001 .{ }^{3}$ After typhoon Minduli in 2004. ${ }^{4}$ After typhoon Airi in 2004. ${ }^{5}$ After typhoon Hytarng in 2005.

A debris flow is usually triggered by heavy rainfall over mountainous areas. It is made up of mud, soils, gravels, rocks, and water. Solids or soils on steep 
slopes slide downward due to weathering processes and mechanical influence such as gravity. From the occurrence of the debris flow hazard in the study area, it is obvious that the weathering process is not the major cause for creating such a large scale of the debris flow hazard. The mechanical influence from the ChiChi earthquake disturbed montane slopes, thus setting the conditions for the occurrence of the regional debris flows.

\subsection{Analysis of rainfall characteristics}

Precipitation exerts two controls on the Ta-Chia river watershed. One is as a trigger of landslide and therefore as materials on the occurrence of debris flows. The other is by providing water, therefore enhancing the mobility of debris flows. To explore the trigger mechanisms of the typhoon-earthquake-typhoon sequence, analysis of rainfall characteristics was conducted in this study. Precipitation data from more than 20 rainfall stations operated by Water Resources Agency of the Taiwan Ministry of Economic Affairs and other government agencies in the watershed were adopted for conducting the rainfall frequency analysis. The results of the frequency analysis were represented as the return period of rainfall. The return period of a storm event is the expected value of its average value measured over a very large number of occurrences. Table 3 is the comparison of accumulated rainfall of 1, 3, 6, 12, and 24 hours for Toraji, Minduli, Airi, and Hytarng typhoon events and the computed return period of rainfall for 2, 10, 25, 50, and 100 years on the upper Gu-Gang rainfall station. From the frequency analysis, we have found that the 1 and 3 hours accumulated rainfall of typhoon Minduli are over the 50-year return period of rainfall. Typhoon Minduli with heavy rainfalls brought sufficient water transporting significant amounts of sparsely deposited debris from landslides in upland into gullies and then induced the regional debris flow hazards.

Table 3: Comparison of accumulated rainfall for major typhoon events and the return period of rainfall on the upper Gu-Gang rainfall station.

\begin{tabular}{|l|l|l|l|l|l|l|l|l|}
\hline $\begin{array}{c}\text { Accumulated } \\
\text { rainfall }\end{array}$ & Toraji & Return period & Minduli & Return period & Airi & Return period & Hytarng & Return period \\
\hline 1 hour $(\mathrm{mm})$ & 77.5 & $\begin{array}{l}75(10 \mathrm{yrs}) \\
85(25 \mathrm{yrs})\end{array}$ & 94.5 & $\begin{array}{l}92(50 \mathrm{yrs}) \\
99(100 \mathrm{yrs})\end{array}$ & 56.5 & $\begin{array}{l}50(2 \mathrm{yrs}) \\
66(5 \mathrm{yrs})\end{array}$ & 28.5 & $50(2 \mathrm{yrs})$ \\
\hline 3 hours $(\mathrm{mm})$ & 173.5 & $174(25 \mathrm{yrs})$ & 199 & $\begin{array}{l}191(50 \mathrm{yrs}) \\
208(100 \mathrm{yrs})\end{array}$ & 158 & $\begin{array}{l}149(10 \mathrm{yrs}) \\
174(25 \mathrm{yrs})\end{array}$ & 63 & $92(2 \mathrm{yrs})$ \\
\hline 6 hours $(\mathrm{mm})$ & 259.5 & $\begin{array}{l}226(10 \mathrm{yrs}) \\
268(25 \mathrm{yrs})\end{array}$ & 271 & $\begin{array}{l}268(25 \mathrm{yrs}) \\
298(50 \mathrm{yrs})\end{array}$ & 297.5 & $298(50 \mathrm{yrs})$ & 117.5 & $133(2 \mathrm{yrs})$ \\
\hline 12 hours $(\mathrm{mm})$ & 317 & $\begin{array}{l}283(5 \mathrm{yrs}) \\
341(10 \mathrm{yrs})\end{array}$ & 394.5 & $\begin{array}{l}341(10 \mathrm{yrs}) \\
411(25 \mathrm{yrs})\end{array}$ & 426 & $\begin{array}{l}411(25 \mathrm{yrs}) \\
461(50 \mathrm{yrs})\end{array}$ & 196 & $193(2 \mathrm{yrs})$ \\
\hline 1 day $(\mathrm{mm})$ & 344.5 & $\begin{array}{l}295(2 \mathrm{yrs}) \\
447(5 \mathrm{yrs})\end{array}$ & 603 & $\begin{array}{l}545(10 \mathrm{yrs}) \\
636(20 \mathrm{yrs})\end{array}$ & 504 & $\begin{array}{l}420(5 \mathrm{yrs}) \\
513(10 \mathrm{yrs})\end{array}$ & 452.5 & $\begin{array}{l}420(5 \mathrm{yrs}) \\
513(10 \mathrm{yrs})\end{array}$ \\
\hline
\end{tabular}

Further analysis also conducted to reveal the spatial distribution of rainfall in the study region. We plotted contours of the 200-year return period of rainfall for each gauging station in Ta-Chia river watershed as shown in Figure 5. Results 
demonstrated that the spatial distribution of the precipitation in the study region mainly concentrated around the upper Gu-Gang rainfall station.

From the results of landslide mapping as shown in Figure 4, we found that the landslides were most located in the areas between Te-Chi dam and Ma-An dam. Comparing Figures 4 and 5, it is found that the regional debris flow hazards in Ta-Chia river watershed are strong related to the spatial distribution of rainfalls.

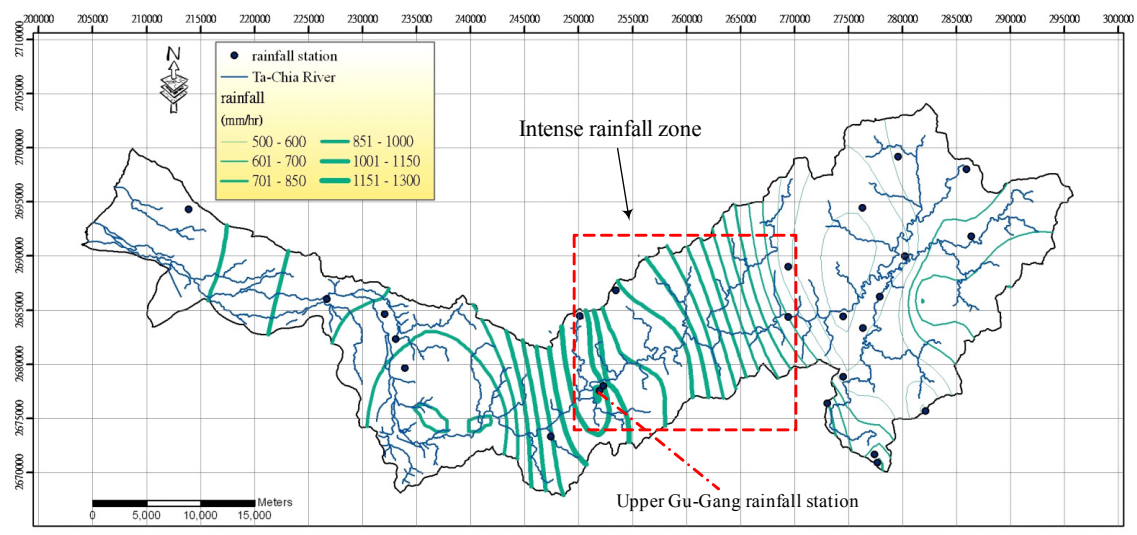

Figure 5: Spatial distribution of rainfall characteristics.

\section{Formation of debris flow}

It is widely recognized that slope instability can be caused by increased subsurface pore pressures during periods of intense rainfall, which reduce the shear strength of slope materials. A number of recent studies have demonstrated that rainfall-induced landslides can be transformed into debris flows as they move downslope. Figure 6 shows multi-temporal aerial-photographs of the formation of a debris flow. In this figure, the four stages including before and after Chi-Chi earthquake, after typhoon Toraji, and after typhoon Minduli of aerial-photographs were presented. Before the Chi-Chi earthquake (1998), it was clear that the branch \# 14 was just a regular gully that the water flow only presents in precipitation. In 1999 (after the Chi-Chi earthquake), landslides initiated from the source areas but no debris flow occurred. In 2001, typhoon Toraji hit this region. The appearance of water flow during storm precipitation is advantageous for mixing with accumulated material from source areas to stir the progression of a beginning landslide into a debris flow. Field reconnaissance of this study area revealed that the trigger mechanism of this debris flow took place in two stages: the primary slope failure was due to the Chi-Chi earthquake from the source area. The hydraulic movement was transferred to the landslide mass of the source area flowing into brook track, following slope surface exposure to the action of running water.

Debris flows are commonly triggered by the sudden increase in pore water pressure on the material. This rapid increase in pore water pressure, however, 
may not always be attributable to the infiltration of precipitation. In this study case, the debris flow resulted from the mixing of rock fragments, fine fractions and water, moving together down gully, and finally deposited in downstream of the gully in which the slope angles for each phase is ranging from about $35,11.5$, and 9.5 degrees, respectively.

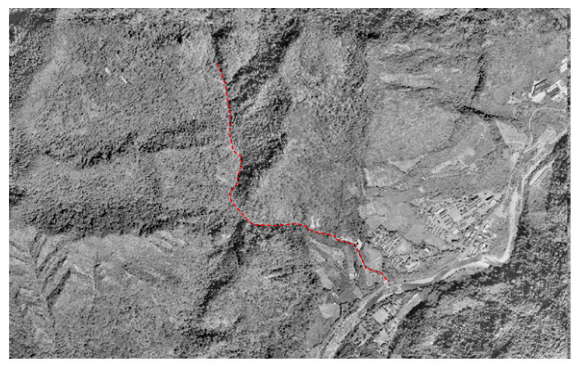

(a) Before the Chi-Chi earthquake(1998)

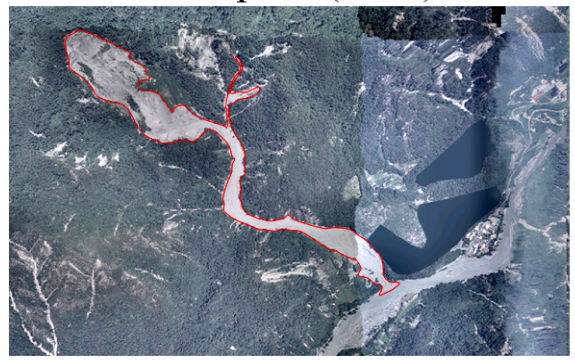

(c) After typhoon Toraji(2001)

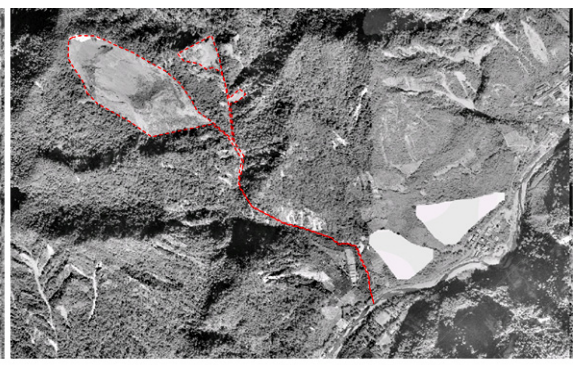

(b) After the Chi-Chi earthquake(1999)

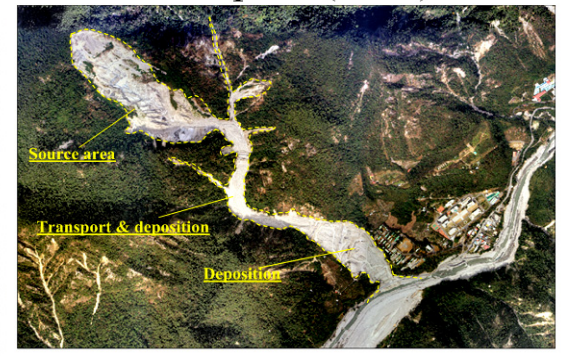

(d) After typhoon Minduli(2004)

Figure 6: Trigger mechanism of the debris flow occurrence in the study area.

\section{Conclusions}

Large-scale debris flow hazards occurred in Ta-Chia River watershed during typhoons that passed through Taiwan from 2001 to 2005 which caused severe property damage and inflicted heavy casualties. In this paper, we present a detailed study on the occurrence of regional debris flow hazards in Ta-Chia River watershed and reveal the trigger mechanism and geomorphological evolution of the landslide and debris flow. Findings from this study are described as following.

Shallow landsliding is the most common landslide type on steep natural hillslopes in the Ta-Chia river watershed. A number of studies have demonstrated that rainfall-induced landslides can be transformed into debris flows as they move downslope. In this study, we have revealed that the Chi-Chi earthquake with the landslide increase rate of $7.15 \%$ is the major event for inducing the landslides and typhoon Minduli with the landslide increase rate of $3.54 \%$ is the second in the study area. From the occurrence of the debris flow 
hazards in the study area, it is obvious that the weathering process is not the major cause for creating such a large scale of the debris flow hazard. The mechanical influence from the Chi-Chi earthquake disturbed montane slopes, thus setting the conditions for the occurrence of the regional debris flows. Analysis results from the spatial distribution of rainfall in the study region demonstrated that the regional debris flow hazards in Ta-Chia river watershed are strong related to the spatial distribution of rainfalls.

\section{References}

[1] Taiwan Power Company, Investigation and Strategy Study of Landslide and Debris flows in Ta-Chia river Basin Between Te-Chi and Ma-An, 2006.

[2] Keefer, D. K., Wilson, R. C., Mark, R. K., Brab, E. E., Brown, W. M., Ellen, S. D., Harp, E. L., Wieczorek, G. F., Alger, C. S., and Zatkin, R. S., Realtime landslide warning during heavy rainfall, Science 238, 921-925, 1987.

[3] Chow, V. T., Maidment, D. R., Mays, L. W., Applied Hydrology, McGrawHill, New York, 1988.

[4] Iverson, R.M., Landslide trigger by rain infiltration. Water Resour Res. 36(7): 1897-1910, 2000.

[5] Maleta J.-P., D. Laigleb, A. Remar trea, O. Maquaire, Triggering conditions and mobility of debris flows associated to complex earthflows, Geomorphology 66 215-235, 2005.

[6] Chen, Hongey, Dadson, Simon, Chi, Yi-Guan, Recent rainfall-induced landslides and debris flow in northern Taiwan, 77, 112-125, Geomorphology, 2006. 